\title{
ANALISIS ETNOGRAFI ALAT MUSIK TRADISIONAL GESO'-GESO' DARI TORAJA
}

\author{
Aris Bidang ${ }^{1)}$, Wahyu Lestari ${ }^{2)}$ \\ Pendidikan Seni Pascasarjana Universitas Negeri Semarang \\ Email: Aristoraja874@students.unnes.ac.id
}

\begin{abstract}
Abstrak
Salah satu alat musik tradisional unik yang ada di Toraja adalah Geso-Geso. Alat musik Geso'Geso' merupakan musik tradisional yang bunyinya bersumber dari senar. Geso-Geso didesain sederhana dengan adanya ruang yang disebut resonator, terbuat dari tempurung kelapa dan kulit hewan, misalnya kulit biawak sebagai penutupnya. Geso'-Geso' terdiri dari finger board, namun tidak mempunyai freat. Uniknya, senar yang digunakan alat musik ini hanya satu. Cara memainkan alat musik ini yaitu dengan cara digesek menggunakan penggesek khusus yang terbuat dari serabut ijuk (kajo).
\end{abstract}

Kata Kunci: Etnografi, Musik Tradisional, Geso'-Geso', Toraja

\begin{abstract}
One of the unique traditional musical instruments in Toraja, namely the Geso'-Geso' the Geso'geso' musical instrument, is a traditional music whose sound comes from strings. Geso'-Geso' are designed simply and have a space called a resonator which is made from coconut shells and also from animal skin, for example a monitor lizard as a cover. Geso'-geso' consists of a finger board but has no freat, but the unique thing is that the strings used by this instrument are only one. The way to play this instrument is by rubbing it using a special tool made from fibers (kajo).
\end{abstract}

Keywords: Ethnogrphy, Traditional Music, Geso'-geso', Toraja

Correspondence author: Aris Bidang, Aristoraja874@students.unnes.ac.id, Semarang, and Indonesia

\section{PENDAHULUAN}

Istilah etnografi terdiri dari dua kata, yakni kata ethno (bangsa) dan graphy (menguraikan). Sehingga, etnografi dapat diartikan sebagai usaha untuk menguraikan kebudayaan atau aspekaspek kebudayaan (Moleong, 2002). Pada umumnya, etnografi bertujuan untuk menguraikan suatu kebudayaan secara menyeluruh, yakni dengan melibatkan semua aspek budaya, baik dari segi material seperti artefak budaya sebagai contoh alat-alat, pakaian, bangunan, patung dan lainlain, dan juga yang bersifat abstrak seperti pengalaman, kepercayaan, norma dan bagaimana sistem nilai dalam suatu kelompok yang diteliti (Mulyana, 2003). 
Dr. Amri Marzali mengatakan bahwa jika ditinjau secara harfiah, etnografi merupakan suatu tulisan atau suatu laporan mengenai suatu suku bangsa, dibuat atau ditulis oleh seorang antropolog sebagai hasil penelitian lapangan selama sekian bulan, bahkan sampai sekian tahun. Etnografi adalah pedoman penulis dalam usaha untuk memahami cara orang-orang dalam berinteraksi serta bekerja sama melalui fenomena yang terjadi dalam kehidupan sehari-hari. Dengan kata lain, bahwa seorang penulis harus terlibat langsung dengan objek penulisan dalam melaksanakan dan memahami makna atau dalam menginterpretasi suatu penulisan yang dilakukan sesuai dengan yang terjadi di lapangan(Spradley, n.d.).

Menurut Bronislaw Malinowski (dalam Zakiah, 2005), tujuan etnografi adalah untuk memahami sudut pandang suatu penduduk asli, yang berhubungan dengan kehidupan, untuk mendapatkan pandangannya mengenai dunianya. Oleh sebab itu, penelitian etnografi banyak melibatkan aktivitas belajar mengenai dunia orang yang telah belajar melihat, mendengar, berbicara, berfikir, serta bertindak dengan cara-cara yang berbeda. Etnografi tidak hanya mempelajari masyarakat, namun juga mempelajari secara mendalam fenomena yang terjadi dalam masyarakat.

Musik merupakan salah satu unsur penting dalam serangkaian pertunjukan, baik melalui bentuk pertunjukan adat, sulap akrobat, ataupun lawak. Fungsi musik adalah menghidupkan suasana dan juga memberi aba-aba penonton bahwa pertunjukan akan segera dimulai atau selesai. Lagu yang dipakai untuk mengiringi kesenian mempunyai fungsi dan nilai bagai kebutuhan masyarakat sehingga diharapkan mampu berintegrasi dalam kehidupan sosial yang lebih luas (Lestari, 2012).

Alat musik merupakan instrumen yang secara sengaja diciptakan atau diadaptasikan dengan tujuan untuk menghasilkan bunyi. Alat musik dibuat dalam berbagai bentuk, gaya serta bahan yang berbeda-beda. Menurut sejarah, alat musik awalnya dibuat dari benda-benda sekitar yang mudah ditemukan, seperti kerang atau kulit-kulit binatang dan juga bagian tanaman. Namun seiring perkembangan zaman, alat musik mengalami banyak perubahan, ditandai dengan muncul berbagai macam variasi dan kualitas bahan (Setyawan \& Dzikri, 2016).

Kesenian yang ada dan berkembang di berbagai daerah lebih dikenal dengan istilah kesenian tradisional. Salah satu kesenian yang sering dijumpai dan menjadi ciri khas di masingmasing daerah adalah seni musik tradisional. Menurut Subagyo, musik tradisional lahir dari budaya setempat secara turun-temurun dan bentuk lagu atau iramanya sangat sederhana dan bersifat kedaerahan (Purnomo \& Subagyo, 2010).

Musik tradisional merupakan musik yang secara tradisional dapat diturunkan dari generasi ke generasi. Musik tradisional sebagai bagian dari kebudayaan memiliki fungsi dalam kehidupan masyarakat. Secara umum, fungsi musik tradisional bagi masyarakat ialah sebagai sarana upacara, pengiring tari-tarian, media ekspresi diri, dan hiburan (Majid, 2015). Menurut Sedyawati musik tradisional adalah musik yang digunakan sebagai perwujudan dan nilai budaya yang sesuai dengan tradisi (Rosadi, 2012).

Musik tradisional adalah musik yang diciptakan oleh masyarakat masa lalu, namun sampai saat sekarang masih terus dikembangkan dan dilestarikan secara turun temurun sebagai sarana hiburan dan identitas daerah. Perkembangan musik tradisional ini dipengaruhi oleh aktor atau seniman, jenis musik dan masyarakat luas yang mendengar juga menikmatinya sehingga musik tradisional dapat dijadikan sebagai perbendaharaan seni di masyarakat tradisional, bahkan dapat menyentuh sektor komersial umum (Putri, 2012: 2).

Berbicara mengenai keberadaan musik tradisional, Tana Toraja merupakan salah satu daerah yang memiliki beragam musik tradisional sampai saat ini. Tana Toraja memiliki beberapa jenis musik tradisional, baik musik vokal maupun instrumental. Alat-alat musik tersebut di antaranya adalah pompang, pelle', suling, Geso'-Geso' yang biasanya digunakan atau ditampilkan dalam upacara-upacara adat maupun ritual-ritual keagamaan di Tana Toraja (Sofyana, 2015: 12).

Tana Toraja terkenal akan alam dan budayanya yang sangat kental. Dari segi panorama alam, sebagian besar wilayah Toraja berisi perbukitan, pegunungan, dan lembah hijau yang dapat mengundang para wisatawan dari mancanegara maupun lokal. Dari segi budaya, Toraja memiliki 
berbagai alat musik tradisional yang muncul dan menjadi suatu tolok ukur pengembangan budaya kesenian tradisional. Salah satunya adalah alat musik Geso'-Geso'. Dalam praktiknya, masyarakat Tana Toraja menggunakan Geso'-Geso' dalam menyelenggarakan upacara tradisional, seperti upacara kematian, perkawinan, kelahiran dan syukuran.

Melihat dari fungsi dan bentuk penyajiannya, maka hal tersebut membuat penulis tertarik untuk mengkaji dan menganalisis Geso '-Geso' sebagai alat musik tradisional yang dimiliki oleh masyarakat Toraja'.

\section{METODE PENELITIAN}

Dalam penelitian di bidang seni, seperti halnya penelitian kualitatif lainnya, dibutuhkan beberapa waktu untuk mendapatkan data atau informasi mendalam, baik yang dilakukan melalui keterlibatan di dalam lapangan maupun melalui situasi kehidupan nyata (Rohindi, 2011). Metode yang digunakan dalam penelitian seni ini adalah metode kualitatif dengan pendekatan musikologi. Metode ini akan membantu penulis dalam menjelaskan secara teliti bagaimana latar belakang beserta hal-hal yang berkenaan dengan Geso'-Geso' di Toraja.

Penelitian kualitatif yang dinyatakan Kirk \& Miller pada awalnya bersumber atau muncul pada pengamatan kualitatif yang bertolak belakang dengan penelitian kuantitatif, sehingga metodologi kualitatif merupakan tradisi tertentu dalam anggapan tentang ilmu pengetahuan sosial yang secara fundamental bertitik pada pengamatan manusianya sendiri dengan berpedoman dengan pemahaman sendiri dan (Moha \& Sudrajat, 2019: 2).

Teknik pengumpulan data yang digunakan dalam metode penelitian kualitatif adalah lewat wawancara, narasi yang bersumber dari aktivitas di masyarakat, melalui pengamatan, dam pengumpulan dokumen. Dalam menjabarkan data-data dengan baik tentang pendekatan dan jenis penelitian, peneliti bias terjun langsung lokasi penelitian untuk mendapatkan sumber-sumber data, cara pengumpulan data, kemudian menganalisis data, kemudian melakukan pengecekan keabsahan terhadap temuan yang dapat disusun dalam bentuk proposal dan juga laporan penelitian yang di dasarkan pada masing-masing konsep (Djelantik, 1999: 1).

Penelitian ini akan menggunakan pendekatan Etnomusikologi (Merriam, 1964). Pendekatan etnomusikologi berfokus analisis materi music, seperti unsur-unsur musik, instrumen musik, maupun struktur komposisi musik. Kajiannya berfokus pada musik suku-suku atau etnis tertentu (Pradoko, 2007: 7).

Penelitian ini juga menggunakan metode penelitian kualitatif dengan model interpretatif. Artinya perolehan data berasal dari lapangan dengan melakukan pengamatan dan wawancara mendalam, kemudian dideskripsikan bentuk pertunjukan kesenian pathol sarang, diinterpretasikan dengan teori-teori atau konsep bentuk pertunjukan dan teori interaksi sosial (Rakanita et al., 2015).

\section{HASIL DAN PEMBAHASAN}

Alat musik Geso'-Geso' adalah alat musik etnik, salah satu warisan yang perlu diturunkan dari generasi ke generasi. Geso'-Geso' pun juga menjadi alat musik yang sering ditampilkan dalam ritual-ritual kebudayan di Toraja secara khusus di acara rambu Tuka',

Aluk Rambu Tuka' disebut juga Aluk Rampe Matallo yaitu ritus-ritus sebelah timur sebagai ritus-ritus persembahan untuk kehidupan, ditujukan kepada dewa-dewa dan para leluhur di sebelah Timur Laut yang dimaknai sebagai permohonan berkat dan kebutuhan hidup di dunia (Kobong, 2008: 54). Selain dalam Rambu Tuka' dan juga sering digunakan sebagai alat pertunjukkan dalam kegiatan-kegiatan pertunjukan alat musik tradisional di Toraja. 


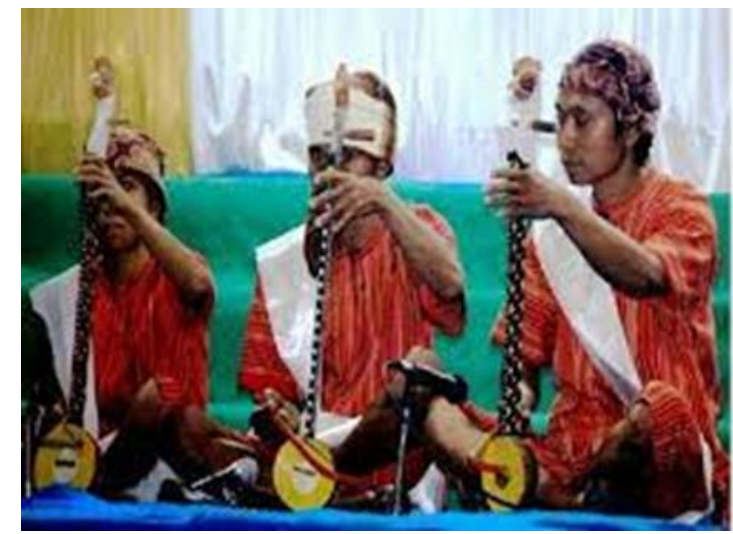

Gambar 1 Geso'-Geso' dimainkan di acara Rambu Tuka'

Selain itu, alat musik ini juga digunakan sebagai alat untuk mengekspresikan perasan sesorang. Menurut tokoh-tokoh musik tradisional, khususnya yang mengenal akan alat musik Geso'-Geso', alat musik ini muncul dengan dilatarbelakangi oleh pemahaman mitos tentang anak yang hilang, sehingga secara bunyi, alat musik ini merupakan musik yang sebenarnya bernuansa sedih.

Menurut Kanu Hizbam (Hizbam, n.d.), Geso'-Geso' merupakan alat musik khas yang umumnya dibuat dari kayu yang bersifat keras dan juga kuat, dengan tambahan tempurung kelapa yang berlapiskan kulit dari binatang yang berfungsi sebagai tabung resonansi untuk memperbesar bunyi. Kulit binatang yang digunakan adalah kulit biawak. Cara memainkannya yaitu digesek. Untuk penggeseknya sendiri terbuat dari serat kayu atau ijuk. Berbeda dengan biola, Geso'-Geso' hanya memiliki satu dawai saja. Dawai atau senar ini terbuat dari riti atas tasi.

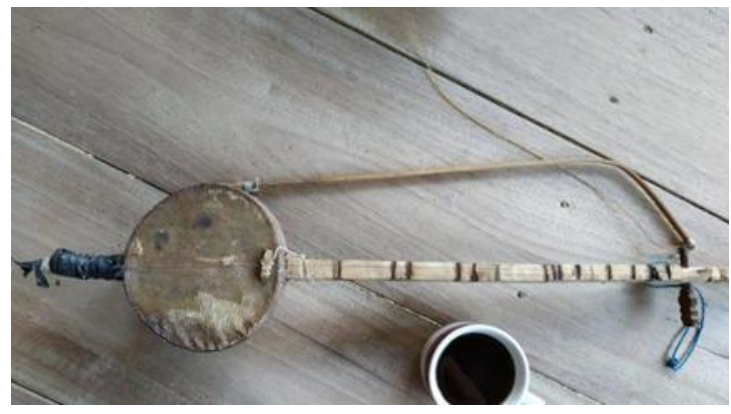

Gambar 2 Bentuk alat musik Geso'-Geso'

Mengenai nada, tidak ada nada khusus yang dihasilkan oleh alat musik Geso'-Geso' Hanya saja, nada yang dihasilkan akan sesuai dengan feeling dari orang yang menyetem atau memainkan alat musik tersebut. Alat ini bisa dimainkan secara individu atau berkelompok. Apabila alat ini dimainkan secara berkelompok, maka yang dilakukan untuk menyamakan nada adalah dengan menyelaraskan bunyi masing-masing alat musik Geso'-Geso' pada setiap pemain sehingga terdengar harmonis, namun nada yang dihasilkan oleh masing-masing pemain harus berbeda satu sama lain.

Dalam penyajiannya, alat musik ini tidak ada unsur campuran musik vokal. Umumnya, alat musik ini hanya dimainkan sebagai instrumen tunggal.

Berdasarkan wawancara dengan Andarias Lolo Layuk, musik Geso'-Geso' awalnya muncul dalam suatu mimpi atau diala mammak yang konon merupakan suatu petunjuk dari deata atau Tuhan untuk melakukan sesuatu hal yang semestinya. 
Menurut Layuk, tidak ada nada atau tangga nada khusus yang mengikat musik Geso'Geso' tetapi nada pada musik tersebut bisa didapatkan dengan menyeimbangkan dan menyelaraskan harmoninya saja.

Terkait dengan pembuatan alat musik Geso'-Geso', berdasarkan wawancara dengan Marten Arruang Tandirerung, diketahui bahwa bahan pembuatan musik Geso'-Geso' terbuat dari balok yang besar yang kemudian dibuat dan dibentuk sedemikian rupa. Mengenai senar, beliau mengemukakan bahwa senar musik ini bukan dari riti atau tasi, tetapi terbuat dari bulu ijuk atau induk pohon aren, atau biasa juga disebut samelungna manyang. Cara memainkannya yaitu digesek.

\section{SIMPULAN}

Berdasarkan pembahasan di atas dapat disimpulkan bahwa beragamnya karya seni yang dihasilkan, atau yang muncul dalam kelompok masyarakat merupakan hal yang sangat perlu untuk diberi perhatian sehingga karya seni tersebut dapat diturunkan dari generasi ke generasi berikutnya termasuk dengan alat musik tradisional Geso'-Geso'. Dalam menganalisis suatu karya seni, dalam hal ini alat musik Geso'-Geso' sebagai suatu musik, perlu diketahui apa yang menjadi unsur-unsur musik yang terdapat dalam alat musik tersebut. Kaitannya dengan itu alat musik Geso'-Geso' sendiri tidak terikat pada nada khusus atau tidak ada nada yang paten yang digunakan ataupun yang mengikatnya sehingga cara untuk memainkan alat musik Geso'-Geso', para pemain musik hanya perlu mencari nadanya berdasarkan feeling..

\section{DAFTAR PUSTAKA}

Bahatmaka, A., \& Lestari, W. (2012). Fungsi musik dalam kesenian Kuntulan Kuda Kembar di Desa Sabarwangi Kecamatan Kajen Kabupaten Pekalongan sebagai sarana integrasi sosial. Catharsis, 1(2). http://journal.unnes.ac.id/sju/index.php/catharsis

Djelantik, A. A. M., Rahzen, T., \& Suryani, N. N. M. (1999). Estetika: sebuah pengantar. Masyarakat Seni Pertunjukan Indonesia.

Hizbam, K. (n.d.). Mengenal 10 alat musik tradisional khas Sulawesi.

Kobong, H. (2008). Injil dan Tongkonan. BPK Gunung Mulia.

Lestari, W. (2000). Peran lokal genius dalam kesenian lokal (The role of local genius in the local art). Harmonia: Journal of Arts Research and Education, 1(2).

Majid, A. (2015). Eksistensi, Bentuk penyajian dan fungsi kesenian tradisional Orek-Orek di Kabupaten Rembang. 1-94.

Moha, I., \& Sudrajat, D. (2019). Resume ragam penelitian kualitatif. https://doi.org/10.31227/osf.io/wtncz

Moleong, J. L. (2002). Metode penelitian kualitatif. Remaja Rosdakarya.

Mulyana, D. (2003). Metode penelitian kualitatif. Remaja Rosdakarya.

Pradoko, A. M. S. (2007). Etnomusikologi. Fakultas Bahasa dan Seni.

Purnomo, W., \& Subagyo, F. (2010). Terampil bermusik untuk SMP dan MTs.

Putri, N. (2012). Efektifitas penggunaan media video untuk pada pembelajaran IPS bagi anak tunagrahita ringan. Jurnal Ilmiah Pendidikan Khusus, 1(2), 318-328. 
Rakanita, D. A. K., Wahyu, L., \& Hartono. (2015). Pertunjukan kesenian Pathol Sarang di Kabupaten Rembang. Catharsis, 4(2), 107-114.

Rohindi, T. R. (2011). Metodologi pendidikan seni. Cipta Prima Nusantara Semarang.

Rosadi, O. S. (2012). Teknik permainan instrumen dan fungsi musik tradisional Phek Bung. 1117.

Setyawan, R. A., \& Dzikri, A. (2016). Analisis penggunaan metode marker tracking pada augmented reality alat musik tradisional Jawa Tengah. Simetris: Jurnal Teknik Mesin, Elektro Dan Ilmu Komputer, 7(1), 295. https://doi.org/10.24176/simet.v7i1.517

Spradley, J. (n.d.). Metode Etnografi.

Wijaya, R., \& Sofyana, P. R. (2015). Suku Toraja (p. 12). Institut Seni Indonesia.

Zakiah, K. (2005). Penelitian Etnografi Komunikasi: Tipe dan Metode. 